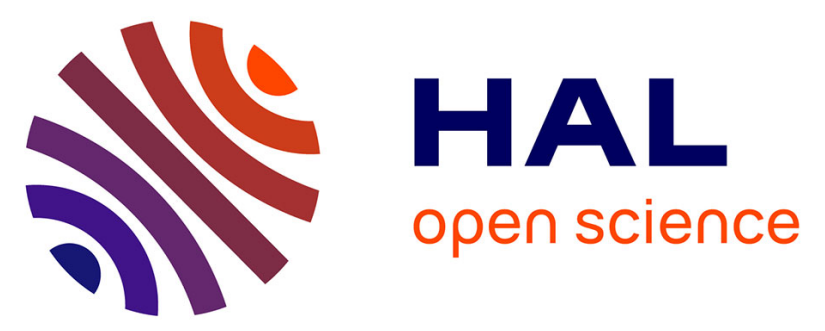

\title{
Is the breast-conserving treatment with radiotherapy appropriate in mutation carriers? Long-term results and review of the literature
}

\author{
Youlia M. Kirova, Alexia Savignoni, Brigitte Sigal-Zafrani, Anne
}

Rochefordiere, Rémy J. Salmon, Pascale This, Bernard Asselain, Dominique

Stoppa-Lyonnet, Alain Fourquet

\section{To cite this version:}

Youlia M. Kirova, Alexia Savignoni, Brigitte Sigal-Zafrani, Anne Rochefordiere, Rémy J. Salmon, et al.. Is the breast-conserving treatment with radiotherapy appropriate in mutation carriers? Long-term results and review of the literature. Breast Cancer Research and Treatment, 2009, 120 (1), pp.119-126. 10.1007/s10549-009-0685-6 . hal-00535424

\section{HAL Id: hal-00535424 https://hal.science/hal-00535424}

Submitted on 11 Nov 2010

HAL is a multi-disciplinary open access archive for the deposit and dissemination of scientific research documents, whether they are published or not. The documents may come from teaching and research institutions in France or abroad, or from public or private research centers.
L'archive ouverte pluridisciplinaire HAL, est destinée au dépôt et à la diffusion de documents scientifiques de niveau recherche, publiés ou non, émanant des établissements d'enseignement et de recherche français ou étrangers, des laboratoires publics ou privés. 


\title{
Is the breast-conserving treatment with radiotherapy appropriate in BRCA1/2 mutation carriers? Long-term results and review of the literature
}

\author{
Youlia M. Kirova - Alexia Savignoni - Brigitte Sigal-Zafrani • \\ Anne de La Rochefordiere - Rémy J. Salmon - Pascale This • \\ Bernard Asselain · Dominique Stoppa-Lyonnet · Alain Fourquet
}

Received: 17 November 2009/Accepted: 9 December 2009/Published online: 24 December 2009

(C) Springer Science+Business Media, LLC. 2009

\begin{abstract}
As tumours in BRCA1/2 mutation carriers might be more sensitive to radiation, we investigated after long-term follow-up whether mutation status influenced the rate of ipsilateral and contralateral breast cancers after breast-conserving treatment (BCT). BRCAl and BRCA2 genes were screened for germline mutations in 131 patients with a family history of breast and/or ovarian cancer who had undergone BCT and radiotherapy. Patients were matched to 261 controls with sporadic breast cancer according to age at diagnosis and year of treatment. Controls were followed up for at least as long as the interval between
\end{abstract}

This article was presented at Breast Cancer Symposium in October 2009, San Francisco, USA.

This study is conducted for the Institut Curie Breast Ovary Cancer Risk Study Group.

Y. M. Kirova $(\bowtie) \cdot$ A. de La Rochefordiere · A. Fourquet

Department of Radiation Oncology, Institut Curie,

26 Rue d'Ulm, 75248 Paris Cedex 05, France

e-mail: youlia.kirova@curie.net

A. Savignoni · B. Asselain

Department of Biostatistics, Institut Curie,

Paris Cedex 05, France

B. Sigal-Zafrani

Department of Pathology, Institut Curie, Paris Cedex 05, France

R. J. Salmon

Department of Surgery, Institut Curie, Paris Cedex 05, France

P. This · D. Stoppa-Lyonnet

Department of Oncology Genetics, Institut Curie,

Paris Cedex 05, France

D. Stoppa-Lyonnet

University Paris Descartes, Paris, France diagnosis and genetic screening in familial cases. Rates of ipsilateral and contralateral cancer between groups were compared by the log-rank test. The BRCAl/2 mutations occurred in $20.6 \%$ of tested patients. Tumours in mutation carriers were more likely to be grade III $\left(P<10^{-4}\right)$ and oestrogen receptor negative $(P=0.005)$ than in non-carriers and controls. Overall median follow-up was 161 months. There was no significant difference in ipsilateral tumours between mutation carriers, non-carriers and controls $(P=0.13)$. On multivariate analysis, age was the most significant predictor for ipsilateral recurrence $\left(P<10^{-3}\right)$. The rate of contralateral cancer was significantly higher in familial cases: $40.7 \%$ (mutation carriers), $20 \%$ (non-carriers), and $11 \%$ (controls) $\left(P<10^{-4}\right)$. After 13.4 years of follow-up, the rate of ipsilateral tumours was no higher in mutation carriers than in non-carriers or controls. As tumours in BRCA1/2 mutation carriers might be more sensitive to radiation, $\mathrm{BCT}$ is a possible treatment option.

Keywords BRCA1/2 mutations .

Breast-conserving treatment $\cdot$ Radiotherapy $\cdot$ Recurrence

\section{Introduction}

BRCA1 and BRCA2 mutations are found in approximately $5 \%$ of all breast cancers and in up to $20-25 \%$ of tumours in patients with a family history of breast and/or ovarian cancer [1]. BRCA1 mutation carriers develop tumours of a higher grade and proliferation index, with lower oestrogen receptor levels than patients with no such mutation, and tend to have worse outcomes [2-5]. BRCA2 mutation carriers, on the contrary, present tumours with pathologic features similar to those of sporadic tumours [2-10]. 
Several studies suggest that $B R C A$ gene mutation might influence response to radiation therapy because tumours in $B R C A 1 / B R C A 2$ carriers are more sensitive to ionising radiation [5-12]. The hypothesis that $B R C A$ mutation is associated with increased radio sensitivity was supported by experimental and clinical data [12-19].

Breast-conserving surgery combined with radiation therapy is standard treatment for early stage breast cancer and provides equivalent survival to mastectomy [20-27]. We and other authors demonstrated that the recurrence rate in $B R C A 1 / B R C A 2$ carriers is not increased in this population of patients [28-32]. On the contrary, it is well known that after long latent period, the radiation therapy for breast cancer can induce malignant tumours after a latency of several years $[33,34]$. The risk of second cancers in this population of patients is insufficiently documented [35, 36]. However, its safety in BRCA mutation carriers is a matter of debate, and several studies have compared ipsilateral tumour recurrence after breast-conserving treatment (BCT) in BRCA1 and BRCA2 mutation carriers and patients with sporadic cancers [9, 28-32, 37-41].

As tumours in BRCA mutation carriers might be more sensitive to radiation with increased risk of second primaries, we report after long-term follow-up whether mutation status influenced the rate of ipsilateral tumours after BCT. This analysis was planned in our previously reported study of homogeneous population of BRCA1/2 mutation carriers and their controls, treated at the Institut Curie [28].

\section{Patients and methods}

\section{Patients}

We retrospectively analysed a cohort of women with small breast cancers treated with breast-conserving surgery and radiotherapy at the Institut Curie between 1981 and 2000. These patients had been invited to attend the family cancer clinic of our institute between 1990 and 2001 if they had a family history of breast or ovarian cancer. Patient selection criteria, genetic screening, and information retrieval methods (familial history, age at cancer diagnosis and death of relatives, and current age) have been described earlier [28, 42].

Genetic screening was offered to women who had either (i) two first-degree relatives affected by cancer, one with invasive breast cancer before 41 years of age or with ovarian cancer at any age, or (ii) at least three first- or second-degree relatives from the same lineage affected with invasive breast or ovarian cancer at any age. The index case was one of the affected family members. The probability of being a carrier of a breast cancer predisposing allele mutation was estimated by taking into account the segregation parameters of Claus modified by Easton and by using the MLINK programme [43-45]. Patients were informed about the aims and limitations of genetic screening. A blood sample was collected with their written consent.

A total of 131 patients who had undergone conservative surgery and radiotherapy in our institute (136 breast cancers) were screened. Each case was matched to two controls with no family history of breast cancer. One control had to be excluded because it did not meet our selection criteria, giving a total of 261 sporadic cases (271 breast tumours). Controls were randomly selected from our prospective breast cancer registry of 9179 patients who underwent conservative treatment between 1981 and 2000, as reported earlier [28, 46]. Matching factors included age at diagnosis, year of treatment, and period of follow-up between cases and controls. BRCA status was known in only one patient at diagnosis and treatment. Clinical, pathological, and outcome data were recorded.

All the cases were treated during the same year as their matched controls using the same protocol. Patients underwent wide surgical excision of the primary tumour and, in most cases, axillary lymph node dissection. This was followed by breast irradiation and by regional node irradiation in the cases of node involvement with doses and techniques already described [28, 47-49]. A boost was delivered to the tumour bed whenever indicated. Controls were followed up for at least as long as the time between diagnosis and genetic screening in familial cases.

Statistical analysis

Patient and tumour characteristics were compared by a chisquare or Fisher's exact test for qualitative variables and by ANOVA (comparisons of means) or the Kruskal-Wallis test (comparisons of medians) for quantitative variables.

Survival was determined from the date of diagnosis to the date of death or last follow-up. Ipsilateral recurrencefree interval was defined as the period from the date of diagnosis of breast cancer to the date of the first local recurrence. Time to recurrence was censored at the time of any event prior to local recurrence (death, lymph node recurrence, distant recurrence, contralateral tumour, or second cancer) or at the time of last follow-up. The contralateral tumour-free interval was defined as the period from the date of diagnosis to the date of contralateral breast cancer. In the 5 patients with bilateral cancer at diagnosis, one tumour was considered to be a contralateral tumour occurring at diagnosis (time to event equal to zero).

The Kaplan-Meier method was used to assess the overall survival, ipsilateral recurrence-free survival and contralateral tumour-free survival rates. Event-free survival 
times of $B R C A$ mutation carriers, non-carriers with a history of familial breast cancer and controls with sporadic disease were compared using the log-rank test [50, 51]. The influence of $B R C A$ mutation, adjusted for other prognostic factors, was assessed in a multivariate analysis by the Cox proportional hazards model, in a forward stepwise regression procedure [52]. Age, histological nodal status, oestrogen and progesterone receptor status, and Scarff-BloomRichardson grading were entered into the model. Categorical variables were transformed into dummy variables to avoid any assumption concerning the estimation of the relative risks (RRs) between subgroups. Missing values were coded as separate variables when necessary.

We used Splus 2000 software (MathSoft Inc., Seattle, WA).

\section{Results}

Twenty-seven patients (20.6\%) with a family history of breast cancer had a BRCA mutation (19 BRCA1, 8 BRCA2) (21.3\% tumours). As expected, the median probability of being a BRCA carrier was significantly higher in carriers than in non-carriers with a family history of breast cancer (90 [73-98] versus 55 [6-98], $P=0.002$ ).

Patients' characteristics were well balanced in the three groups. Median age was 43 years [range, 26-60] in BRCA1/2 mutation carriers, 43.5 years [24-78] in noncarriers and 43 years [23-79] in controls $(P=0.92)$. The percentage of patients who were pre-menopausal was 85 , 70 and $76 \%$, respectively $(P=0.24)$. As reported earlier, the familial and sporadic cohorts were well matched with regard to age at diagnosis [26]. Overall median follow-up was 161 months [range 31-297] and was broken down as follows: 167 months [35-230] for BRCA mutation carriers, 161 months [35-270] for non-carriers and 156 months [32-297] for controls. Two BRCAl carriers and 3 noncarriers had synchronous bilateral breast cancers.

Table 1 gives tumour characteristics according to BRCA1/BRCA2 mutation status. The 27 mutation carriers had 29 tumours. These tumours were more likely to be grade III $\left(P<10^{-4}\right)$ and receptor negative $(P=0.02)$ than tumours in either non-carriers or controls, and to be of the medullary subtype. All medullary tumours in patients with familial cancer occurred in patients with BRCA1 mutations. Treatment did not differ significantly amongst groups (Table 2). The only observed difference in hormonal treatment, probably related to hormonal status in carriers (mostly hormonal negative tumours) was not analysed because of the small size of patients in the three groups.

There was no significant difference in ipsilateral tumour recurrence amongst groups $(P=0.13)$ nor between mutation carriers and their matched controls $(P=0.43)$
(Fig. 1a, b). Crude recurrence rates and hazard ratios are given in Table 3 as well as the site of recurrence. Most patients experienced recurrence in the same quadrant as the initial tumour. There was no difference in site according to group. Three of the 6 patients with medullary carcinoma had an ipsilateral recurrence: one in the control group at 79 months and two in the mutation carrier group at 91 and 245 months. In a uni- and multivariate analysis, age was the only significant predictor for local recurrence. The RR of recurrence was 1.05 [1.02-1.07], $\left(P<10^{-3}\right)$ for each decreasing year of age. BRCA mutation status, lymph node status, hormonal receptor status and tumour grade were not significant predictors of local recurrence.

The rate of contralateral breast cancer was significantly higher in mutation carriers than in non-carriers and controls $(P<0.0001)$ and higher in mutation carriers than in their matched controls $(P=0.0011)$ (Fig. 2a, b). There were $40.7 \%$ in the group of $B R C A 1 / 2$ mutation carriers versus $20.2 \%$ in familial cases versus $11.1 \%$ in the group of sporadic controls $\left(P<10^{-4}\right)$. In a uni- and multivariate analysis, $B R C A$ mutation status was the only significant predictor for the risk of developing a contralateral cancer $\left(P<10^{-4}\right)$. Age, lymph node status, hormonal receptor status and tumour grade were not significant predictors.

The role of tamoxifen in the risk of contralateral breast cancer has not been studied because of the increased number of receptor-negative tumours.

There was no significant difference in the overall survival between the three groups (Fig. 3).

\section{Discussion}

This matched retrospective case-control single institutional study with an overall median follow-up of 13.4 years has shown that the rate of ipsilateral tumours was no higher in BRCA1 and BRCA2 mutation carriers than in non-carriers with a family history of breast cancer and in matched controls, despite the fact that tumours with BRCA1 mutations tend to be more aggressive. In order to avoid bias, controls were followed up for at least as long as the time interval between diagnosis and genetic screening in familial breast cancer cases. Our study confirmed the earlier reported increased incidence of contralateral breast cancers. At the same time, there was no difference in the overall survival in the different groups of patients. The main weakness of our study is the limited number of patients and its retrospective nature.

The main case-control studies on ipsilateral tumour recurrence are summarized in Table 4. Our long-term results support the findings of a multi-institutional study in which no significant difference in ipsilateral recurrence was noted between BRCAI/2 mutation carriers $(n=170)$ 
Table 1 Tumour characteristics

a The medullary subtype was more common in BRCAl carriers than in other groups (11.5 vs. 1.1 vs. $0.8 \%$, $P=0.005)$

$N D$ not determined

Table 2 Treatment

\begin{tabular}{|c|c|c|c|c|}
\hline & $\begin{array}{l}\text { BRCA1/2-mutated } \\
\text { tumours } \\
n=29\end{array}$ & $\begin{array}{l}\text { Non-mutated } \\
\text { tumours } \\
n=107\end{array}$ & $\begin{array}{l}\text { Sporadic } \\
\text { controls } \\
n=271\end{array}$ & $P$ \\
\hline \multicolumn{5}{|l|}{ T stage UICC $-n(\%)$} \\
\hline No palpable tumour & $3(10.3)$ & $17(15.9)$ & $49(18.1)$ & \multirow[t]{4}{*}{0.85} \\
\hline $\mathrm{T} 1-2$ & $26(89.7)$ & $85(79.4)$ & $212(78.2)$ & \\
\hline $\mathrm{T} 3$ & 0 & 0 & $1(0.4)$ & \\
\hline $\mathrm{Tx}$ & 0 & $5(4.7)$ & $9(3.3)$ & \\
\hline \multicolumn{5}{|l|}{ Clinical tumour size $(\mathrm{mm})$} \\
\hline Median [Range] & $20[0-35]$ & $15[0-35]$ & $20[0-70]$ & 0.49 \\
\hline \multicolumn{5}{|l|}{$\mathrm{N}$ stage $-n(\%)$} \\
\hline N0 & $26(89.7)$ & $89(84)$ & $243(70.5)$ & \multirow[t]{3}{*}{0.22} \\
\hline N1 & $3(10.3)$ & $17(16)$ & $26(29.5)$ & \\
\hline \multicolumn{4}{|l|}{$\mathrm{Nx}$} & \\
\hline \multicolumn{5}{|c|}{ Pathological nodal status- $n(\%)$} \\
\hline Negative & $21(72.4)$ & $49(45.8)$ & $133(49.1)$ & \multirow[t]{3}{*}{0.13} \\
\hline Positive & $3(10.3)$ & $20(18.7)$ & $41(15.1)$ & \\
\hline No lymph node dissection & $5(17.2)$ & $38(35.5)$ & $97(35.8)$ & \\
\hline \multicolumn{5}{|l|}{ Pathology $-n(\%)$} \\
\hline Ductal invasive & $17(65.4)$ & 77 (84.6) & $216(82.1)$ & \multirow[t]{6}{*}{$<10^{-3 a}$} \\
\hline Lobular invasive & $3(11.5)$ & $10(11.0)$ & $16(6.1)$ & \\
\hline Medullary & $3(11.5)$ & $1(1.1)$ & $2(0.8)$ & \\
\hline Other & $2(7.7)$ & $1(1.1)$ & $12(4.5)$ & \\
\hline DCIS & $1(3.9)$ & $2(2.2)$ & $17(6.5)$ & \\
\hline ND & 3 & 16 & 8 & \\
\hline \multicolumn{5}{|l|}{ Histological grade $-n(\%)$} \\
\hline I, II & $9(31.1)$ & $67(76.1)$ & $166(81.0)$ & \multirow[t]{3}{*}{$<10^{-4}$} \\
\hline III & $14(68.9)$ & $21(23.9)$ & $39(19.0)$ & \\
\hline 'non gradable' + ND & 6 & 19 & 66 & \\
\hline \multicolumn{5}{|l|}{ Oestrogen receptors- $n(\%)$} \\
\hline Negative & $11(47.8)$ & $19(27.5)$ & $33(20.9)$ & \multirow[t]{3}{*}{0.018} \\
\hline Positive & $12(52.2)$ & $50(72.5)$ & $125(79.1)$ & \\
\hline ND & 6 & 38 & 113 & \\
\hline \multicolumn{5}{|c|}{ Progesterone receptors- $n(\%)$} \\
\hline Negative & $11(47.8)$ & $15(21.7)$ & $34(21.7)$ & \multirow[t]{3}{*}{0.02} \\
\hline Positive & $12(52.2)$ & $54(78.3)$ & $123(78.3)$ & \\
\hline ND & 6 & 38 & 114 & \\
\hline & $\begin{array}{l}\text { BRCA1/2-mutated tumours } \\
n=29\end{array}$ & $\begin{array}{l}\text { Non-mutated tumours } \\
n=107\end{array}$ & $\begin{array}{l}\text { Sporadic controls } \\
n=271\end{array}$ & $P$ \\
\hline \multicolumn{5}{|l|}{ Node irradiation } \\
\hline No & $15(51.7)$ & $40(37.4)$ & $108(39.9)$ & \multirow[t]{2}{*}{0.40} \\
\hline Yes & $14(48.3)$ & $67(62.6)$ & $163(60.1)$ & \\
\hline \multicolumn{5}{|l|}{ Whole breast dose [Gy] } \\
\hline Median [range] & $52[45-62]$ & $52[43-62]$ & $52[45-66]$ & 0.87 \\
\hline \multicolumn{5}{|l|}{ Tumour dose [Gy] } \\
\hline Median [range] & $65[50-75]$ & $64[50-78]$ & $65[45-82]$ & 0.75 \\
\hline Boost to tumour bed (\%) & 72 & 61 & 66 & 0.6 \\
\hline Chemotherapy (\%) & 38 & 28 & 25 & 0.29 \\
\hline Hormonal therapy $(\%)$ & 7 & 13 & 6 & 0.045 \\
\hline
\end{tabular}



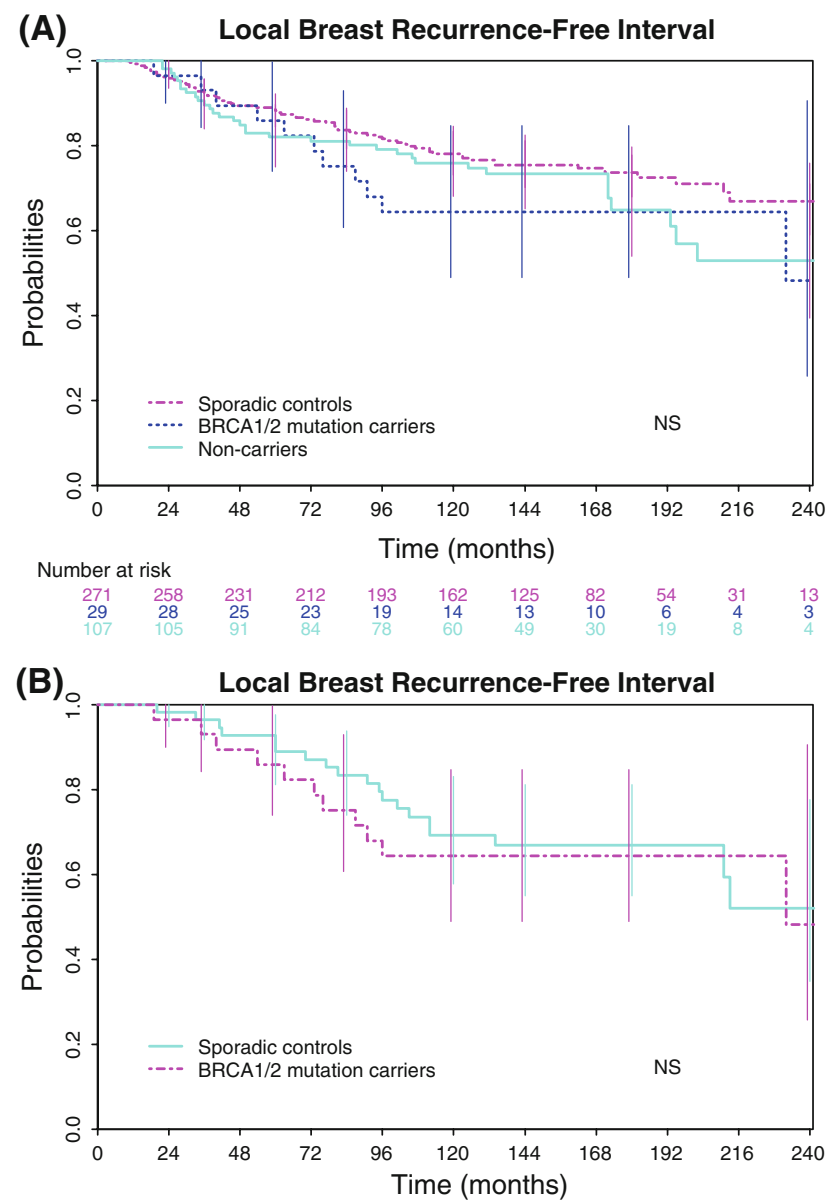

Number at risk

Fig. 1 Ipsilateral recurrence rate: a $B R C A 1 / 2$ mutation carriers versus non-carriers versus sporadic controls, b $B R C A 1 / 2$ mutation carriers versus their matched sporadic controls

Table 3 Description of ipsilateral tumours and their site

\begin{tabular}{|c|c|c|c|c|}
\hline & $\begin{array}{l}B R C A 1 / 2 \text {-mutated } \\
\text { tumours } \\
n=29\end{array}$ & $\begin{array}{l}\text { Non-mutated } \\
\text { tumours } \\
n=107\end{array}$ & $\begin{array}{l}\text { Sporadic } \\
\text { controls } \\
n=271\end{array}$ & $p$ \\
\hline \multicolumn{5}{|l|}{ Ipsilateral } \\
\hline Number & 13 & 33 & 66 & \\
\hline Hazard ratio & $1.8[1-3.3]$ & $1.3[0.8-2.0]$ & 1 & \\
\hline \multicolumn{5}{|l|}{ Site } \\
\hline Same quadrant & 11 & 21 & 48 & 0.33 \\
\hline Other quadrant & 2 & 12 & 18 & \\
\hline
\end{tabular}

and sporadic cases matched by age and date of diagnosis $(n=469)$ after a median follow-up of 8.3 years, reported by Pierce et al. [30]. Matched cohort study described increased recurrence, after adjustment for age, in the hereditary group at 5 years but no significant increase in the 26 BRCA1/2 mutation carriers compared to sporadic cases [38]. The more recent publication of the same team
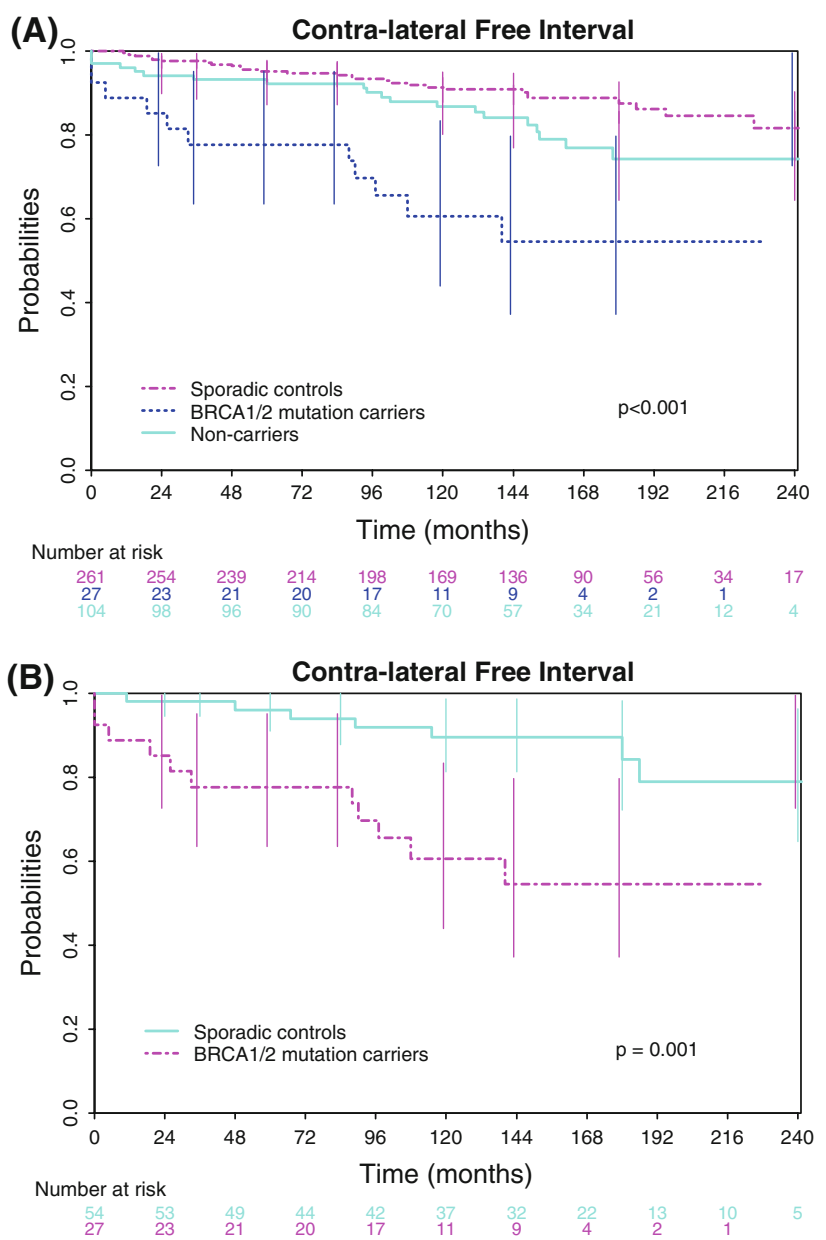

Fig. 2 Contralateral tumour free interval: a $B R C A 1 / 2$ mutations carriers versus non-carriers versus sporadic controls, b BRCA1/2 mutation carriers versus their matched sporadic controls
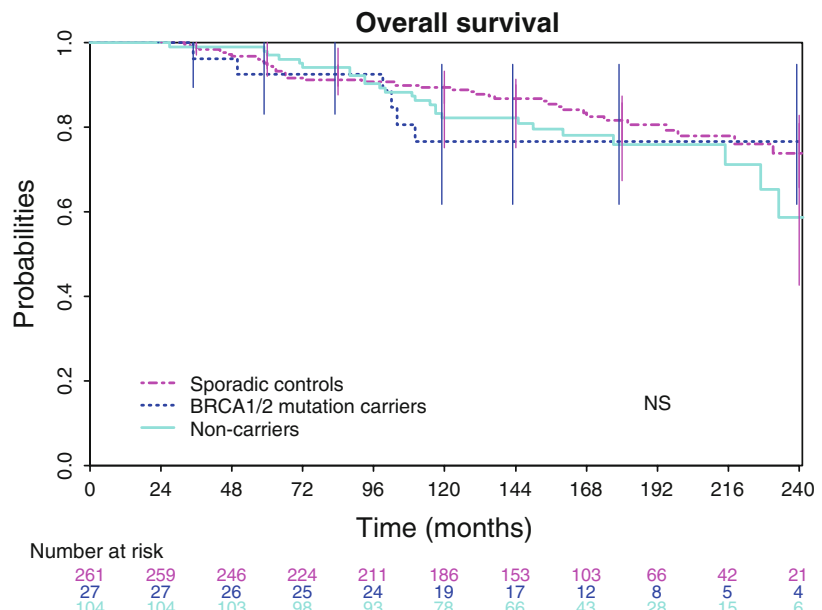

Fig. 3 Overall survival in BRCA1/2 mutation carriers versus noncarriers versus sporadic controls

reported by Brekelmans et al. [31] showed no difference in term of ipsilateral breast recurrence, $P=0.6$ between carriers and controls. Recently published new study of very 
Table 4 Main retrospective studies of ipsilateral recurrence in BRCA carriers treated by BCT and radiotherapy

\begin{tabular}{|c|c|c|c|c|c|c|c|}
\hline & \multirow{2}{*}{$\begin{array}{l}\text { Study period } \\
\text { and type }\end{array}$} & \multirow{2}{*}{$\begin{array}{l}\text { BRCA1/2 } \\
\text { carriers }(N)\end{array}$} & \multirow[t]{2}{*}{ Controls $(N)$} & \multirow{2}{*}{$\begin{array}{l}\text { Median follow up } \\
\text { (years) }\end{array}$} & \multicolumn{2}{|c|}{ Ipsilateral recurrence $(\%)$} & \multirow[t]{2}{*}{$P$} \\
\hline & & & & & Carriers & Controls & \\
\hline Haffty et al. [37] & $1975-1998$ & 22 & 105 & 13 & 49 & 21 & 0.007 \\
\hline Robson et al. [9] & 1980-1995 & 56 & 440 & 9.7 & 12 & 8 & 0.68 \\
\hline Seynaeve et al. [38] & 1980-1995 Matched & 26 & 174 & 6.0 & 21.8 & 12.1 & 0.05 \\
\hline Brekelmans et al. [31] & 1980-2004 Matched & $109(76 / 33)$ & 410 & 4.3 & $12 / 17$ & 12 & 0.6 \\
\hline Pierce et al. [30] & 1980-1997 Matched & 170 & 469 & 8.3 & 12.5 & 8.6 & 0.55 \\
\hline Kirova et al. [28] & 1981-2000 Matched & $29(107)^{\mathrm{a}}$ & 271 & 8.8 & 24 & 19 & 0.47 \\
\hline This study & 1981-2000 Matched & 29 & 58 & 13.4 & 36 & 33 & 0.42 \\
\hline
\end{tabular}

${ }^{a}$ Familial cases

young patients by Garcia-Etienne et al. [41] suggested after median follow-up of 4 years increased rates of ipsilateral breast cancer incidence in mutation carriers (9.3 vs. $2.5 \%$ ) without complete information concerning the radiotherapy modalities (total dose, boost to the tumour bed) is given.

The results of the two non-matched cohort studies in Table 4 are contradictory, no significant difference being found in the Robson et al. study unlike in the Haffty et al. study of a subgroup of 127 patients under 42 years of age $[9,37]$. In the latter study, the significantly higher ipsilateral recurrence rate in $B R C A 1 / 2$ mutation carriers suggests that there might be an increase in the rate of second primary cancers after 10 years. In this study and also in other series, age was a significant predictor of recurrence, supporting the observation that young age rather than $B R C A$ status is a strong predictive factor for local relapse in hereditary breast cancer patients [28, 32].

We observed a significantly higher incidence of contralateral breast cancer in BRCAI/2 carriers than in noncarriers and controls. All studies of BRCA1 and/or BRCA2 mutation carriers so far have reported an increased incidence of contralateral breast cancer $[9,15,28-30,37,38$, 40]. Pierce et al. [30] have reported 10-year actuarial estimates of 26 and $3 \%$ for carriers and sporadic controls, respectively $(P<0.0001)$. Robson et al. [9] reported a $27 \%$ risk in carriers versus an $8 \%$ risk in non-carriers $(P=0.002)$ after 10 years of follow-up. Haffty et al. [37] recorded a $42 \%$ rate in carriers versus a $9 \%$ rate in noncarriers $(P=0.001)$ at 12 years. The high risk of contralateral breast cancer in $B R C A 1 / B R C A 2$ mutation carriers must be taken into account when choosing treatment. If the choice is breast conservation, strategies such as prophylactic oophorectomy and tamoxifen administration with close radiological surveillance should be discussed with the patient [53-55]. Mutation carriers do have a choice as no difference has been noted in overall survival compared to controls. The issue is complex and has been masterly addressed in a recent article [56].
With the new advances in the knowledge of hormonal receptor negative and HER2 negative tumours, new treatment possibilities could be offered this population of patients. The published data suggest that PARP inhibitors could be used not only as chemo/radiotherapy sensitizers, but also as single agents to selectively kill cancers defective in DNA repair, specifically cancers with mutations in the breast cancer associated (BRCA) 1 and 2 genes. This theory of selectively exploiting cells defective in one DNA repair pathway by inhibiting another is a major breakthrough in the treatment of cancer. BRCA1/2 mutations are responsible for the majority of genetic breast/ovarian cancers, known as the hereditary breast ovarian cancer syndrome [57].

In summary, our long-term study has confirmed that the rate of ipsilateral tumour recurrence in $B R C A 1$ and $B R C A 2$ mutation carriers is no higher than in non-carriers or patients without a family history of breast cancer despite the more aggressive features of these tumours. It has also confirmed the higher risk of contralateral breast cancer in mutation carriers. This calls for risk reduction strategies. Since tumours in BRCA carriers appear to be more sensitive to radiation, BCT may be considered in $B R C A$ mutation carriers after discussion with the patient.

Acknowledgements To: M. C. Falcou, M. Gauthier-Villars, A. de Pauw, B. Buecher, C. Houdayer for their help and their competence.

\section{References}

1. Robson ME (2002) Clinical considerations in the management of individuals at risk for hereditary breast and ovarian cancer. Cancer Control 9:457-465

2. Adem C, Reynolds C, Soderberg CL et al (2003) Pathologic characteristics of breast parenchyma in patients with hereditary breast carcinoma, including BRCA1 and BRCA2 mutation carriers. Cancer 97:1-11

3. Chappuis PO, Nethercot V, Foules WD et al (2000) Clinicopathological characteristics of BRCA1 and BRCA2-related breast cancer. Semin Surg Oncol 18:287-295 
4. Stoppa-Lyonnet D, Ansquer Y, Dreyfus H et al (2000) Familial invasive breast cancers: worse outcome related to BRCA1 mutations. J Clin Oncol 18:4053-4059

5. Foulkes WD, Chappuis PO, Wong N et al (2000) Primary node negative breast cancer in BRCA1 mutation carriers has a poor outcome. Ann Oncol 11:307-313

6. Verhoog LC, Brekelmans CTM, Seynaeve C et al (1998) Survival and tumour characteristics of breast cancer patients with germline mutations of BRCA1. Lancet 351:316-321

7. Breast Cancer Linkage Consortium (1997) Pathology of familial breast cancer: differences between breast cancers in carriers of BRCA1 or BRCA2 mutations and sporadic cases. Lancet 349:1505-1510

8. Lakhani SR, Jacquemier J, Sloane JP et al (1998) Multifactorial analysis of differences between sporadic breast cancers and cancers involving BRCA1 and BRCA2 mutations. J Natl Cancer Inst 90:1138-1145

9. Robson M, Chappuis PO, Satagopan J et al (2004) A combined analysis of outcome following breast cancer: differences in survival based on BRCA1/BRCA2 mutation status and administration of adjuvant treatment. Breast Cancer Res 6:R8-R17

10. Venkitaraman A (2002) Cancer susceptibility and the functions of BRCA1 and BRCA2. Cell 108:171-182

11. Powel SN, Kachnic LA (2003) Roles of BRCA1 and BRCA2 in homologous recombination, DNA replication fidelity and the cellular response to ionising radiation. Oncogene 22:5784-5791

12. Baeyens A, Thierens H, Claes $\mathrm{K}$ et al (2002) Chromosomal radiosensitivity in breast cancer patients with a known or putative genetic predisposition. Br J Cancer 87:1379-1385

13. Freneaux P, Stoppa-Lyonnet D, Mouret E et al (2000) Low expression of bcl-2 in Brca1-associated breast cancers. $\mathrm{Br} \mathrm{J}$ Cancer 83:1318-1322

14. Hedenfalk I, Duggan D, Chen Y et al (2001) Gene-expression profiles in hereditary breast cancer. N Engl J Med 344:539-548

15. Cortez D, Wang Y, Qin J et al (1999) Requirement of ATMdependent phosphorylation of Brcal in the DNA damage response to double-strand breaks. Science 286:1162-1166

16. Scully R, Chen J, Ochs RL et al (1997) Dynamic changes of BRCA1 subnuclear location and phosphorylation state are initiated by DNA damage. Cell 90:425-435

17. Xu X, Weaver Z, Linke SP et al (1999) Centrosome amplification and a defective G2-M cell cycle checkpoint induce genetic instability in BRCA1 exon 11 isoform-deficient cells. Mol Cell 3:389-395

18. Brodie SG, Xu X, Qiao W et al (2000) Multiple genetic changes are associated with mammary tumorigenesis in BRCA1 conditional knockout mice. Oncogene 20:7514-7523

19. Fourquet A, Stoppa-Lyonnet D, Sigal-Zafrani B et al (2009) Familial invasive breast cancer: clinical response to induction chemotherapy or radiotherapy related to BRCA1 and BRCA2 mutations. Am J Clin Oncol 32:127-131

20. Fisher B, Anderson S, Bryant J et al (2002) Twenty-year followup of a randomised trial comparing total mastectomy, lumpectomy and lumpectomy plus irradiation for the treatment of invasive breast cancer. N Engl J Med 347:1233-1241

21. Clark R, McCullock P, Levine M et al (1992) Randomised clinical trial to assess the effectiveness of breast irradiation following lumpectomy and axillary dissection for node-negative breast cancer. J Natl Cancer Inst 84:683-689

22. Van Dongen JA, Voogd AC, Fentiman IS et al (2000) Long-term results of a randomized trial comparing breast-conserving therapy with mastectomy: EORTC 10801 trial. J Natl Cancer Inst 92:1143-1150

23. Veronesi U, Cascinelli N, Mariani L et al (2002) Twenty-year follow-up of a randomised study comparing breast-conserving surgery with radical mastectomy for early breast cancer. N Engl J Med 347:1227-1232

24. Jacobson JA, Danforth DN, Cowan KH et al (1995) Ten-year results of a comparison of conservation with mastectomy in the treatment of stage I and II breast cancer. N Engl J Med 332:907-911

25. Blichert-Toft M, Roce C, Anderson JA et al (1992) Danish randomised trial comparing breast conservation therapy with mastectomy: six years of life table analysis. Danish Breast Cancer Cooperative group. J Natl Cancer Inst Monograms 11:19-25

26. Arriagada R, Le MG, Guinebretière JM et al (2003) Late local recurrences in a randomised trial comparing conservative treatment with total mastectomy in early breast cancer patients. Ann Oncol 14:1617-1622

27. Early Breast Cancer Trialists' Collaborative Group (2005) Effects of radiotherapy and of differences in the extent of surgery for early breast cancer on local recurrence and 15-year survival: an overview of the randomised trials. Lancet 366:2087-2106

28. Kirova YM, Stoppa-Lyonnet D, Savignoni A et al (2005) Risk of breast cancer recurrence and contralateral breast cancer in relation to BRCA1 and BRCA2 mutation status following breastconserving surgery and radiotherapy. Eur J Cancer 41:2304-2311

29. Pierce LJ, Strawderman M, Narod SA et al (2000) Effect of radiotherapy after breast-conserving treatment in women with breast cancer and germline BRCA1/2 mutations. J Clin Oncol 18:3360-3369

30. Pierce L, Levin A, Rebbeck $\mathrm{T}$ et al (2006) Ten-year multiinstitutional results of breast-conserving surgery and radiotherapy in BRCA1/2-associated stage I/II breast cancer. J Clin Oncol 24:2437-2443

31. Brekelmans CT, Tilanus-Linthorst MM, Seynaeve C et al (2007) Tumour characteristics, survival and prognostic factors of hereditary breast cancer from BRCA2-, BRCA1- and nonBRCA1/2 families as compared to sporadic breast cancer cases. Eur J Cancer 43(5):867-876

32. Delaloge S, Kloos I, Ariane D et al (2003) Young age is the major predictor of local relapse among conservatively treated BRCA1-, BRCA2-, or non BRCA-linked hereditary breast cancer. ASCO Proc 22(abstr 41):11

33. Kirova YM, De Rycke Y, Gambotti L et al (2008) Second malignancies after breast cancer: the impact of different treatment modalities. Br J Cancer 98:870-874

34. Kirova Y, Vilcoq JR, Asselain B et al (2005) Radiation-induced sarcomas (RIS) following radiotherapy for breast cancer: a largescale single institution review. Cancer 104:856-863

35. Thompson D, Easton DF (2002) The breast cancer linkage consortium: cancer incidence in BRCA1 mutation carriers. J Natl Cancer Inst 94:1358-1365

36. Kirova YM, Fourquet A, Savignoni A et al (2006) Risk of second non breast malignancies (SNBM) in relation to BRCA1 and BRCA2 mutation status following breast-conserving surgery and radiotherapy. Am J Immunol 2:61-63

37. Haffty BG, Harrold E, Khan AJ et al (2002) Outcome of conservatively managed early-onset breast cancer by BRCA1/ BRCA2 status. Lancet 359:1471-1477

38. Seynaeve C, Verhoog LC, Van De Bosch LM et al (2004) Ipsilateral breast tumour recurrence in hereditary breast cancer following breast-conserving therapy. Eur J Cancer 40:1150-1158

39. Bremer M, Doerk T, Sohn C et al (2003): Local relapse after postoperative radiotherapy in patients with bilateral breast cancer by BRCA1/2 status. ASCO Proc 22(abstr 42):11

40. Turner BC, Harrold E, Matloff E et al (1999) BRCA1/BRCA2 germline mutations in locally recurrent breast cancer patients after lumpectomy and radiation therapy: implications for breastconserving management in patients with BRCA1/BRCA2 mutations. J Clin Oncol 17:3017-3024 
41. Garcia-Etienne CA, Barile M, Gentilini OD et al (2009) Breastconserving surgery in BRCA1/2 mutation carriers: are we approaching an answer? Ann Surg Oncol (in press)

42. Stoppa-Lyonnet D, Laurent-Puig P, Essioux L et al (1997) BRCA1 sequence variations in 160 individuals referred to a breast/ovarian family cancer clinic. Institut Curie Breast Cancer Group. Am J Hum Genet 60:1021-1030

43. Wagner T, Stoppa-Lyonnet D, Fleischmann E et al (1999) Denaturing high-performance liquid chromatography detects reliably BRCA1 and BRCA2 mutations. Genomics 62:369-376

44. Claus EB, Risch N, Thompson WD (1991) Genetic analysis of breast cancer in the cancer and steroid hormone study. Am J Hum Genet 48:232-242

45. Easton DF, Bishop DT, Ford D et al (1993) Genetic linkage analysis in familial breast and ovarian cancer: results from 214 families. The Breast Cancer Linkage Consortium. Am J Hum Genet 52:678-701

46. Salmon RJ, Asselain B, Le Gal M et al (1997) Twelve years experience of breast cancer at the Institut Curie: improvement of survival and value of screening mammographics. Breast 6:202-205

47. Kirova Y, Servois V, Campana F et al (2006) CT- scan based localization of the internal mammary chain and supra clavicular nodes for breast cancer radiation therapy planning. Radiother Oncol 79:310-315

48. Campana F, Kirova YM, Rosenwald JC et al (2005) Breast radiotherapy in the lateral decubitus position-a technique to prevent lung and heart irradiation. Int J Radiat Oncol Biol Phys 61:1348-1354
49. Kirova YM, Fournier-Bidoz N, Servois V et al (2008) How to boost the breast tumor bed? A multidisciplinary approach in 8 steps. Int J Radiat Oncol Biol Phys 72:494-500

50. Kaplan EL, Meier P (1958) Non-parametric estimation from incomplete observations. J Am Stat Assoc 53:457-481

51. Mantel N (1966) Evaluation of survival data and two new rank order statistics arising in its consideration. Cancer Chemother Rep 50:163-170

52. Cox DR (1972) Regression models and life tables. J R Stat Soc 34:187-220

53. Narod SA, Brunet JS, Ghadirian P et al (2000) Tamoxifen and risk of contralateral breast cancer in BRCA1 and BRCA2 mutation carriers: a case-control study. Lancet 356:1876-1881

54. Pierce L (2002) Radiotherapy for breast cancer in BRCA1/ BRCA2 carriers: clinical issues and management dilemmas. Semin Radiat Oncol 12:352-361

55. Meijers-Heijboer EJ, Verhoog LC, Brekelmans CTM et al (2000) Presymptomatic DNA testing and prophylactic surgery in families with a BRCA1 or BRCA2 mutation. Lancet 355:2015-2020

56. Reicht A (2009) Contralateral prophylactic mastectomy: caveat emptor. J Clin Oncol 27:1347-1349

57. Drew Y, Calvert H (2008) The potential of PARP inhibitors in genetic breast and ovarian cancers. Ann N Y Acad Sci 1138:136145 